\title{
Analisis Inflasi di Indonesia (Suatu Pendekatan Model Dinamik)
}

\author{
Afrizal* \\ Fakultas Ekonomi dan Bisnis, Universitas Tanjungpura, Indonesia
}

\begin{abstract}
This study aims to determine the magnitude of the effect of the money supply, the exchange rate of rupiah (exchange rate) and the interest rate on inflation in Indonesia during the period 2000.12016.4. The analysis tools used for this research data are: unit root test, integration degree test, cointegration test, Error Correction Model (ECM). The results showed that all staioner research data at level 1 (first difference) based on cointegration test showed that the variables observed in this study co-integration or have long-term relationship. The ECM model used is valid, as indicated by the Error Correction Term (ECT) coefficient is significant. In the short run the money supply, the exchange rate of rupiah (exchange rate) and the interest rate is not significant to the inflation rate, but in the long term is significant.
\end{abstract}

Keywords: inflation, money supply, rupiah exchange rate, interest rate, cointegration test, error correction model

\section{PENDAHULUAN}

Inflasi merupakan merupakan fenomena ekonomi dan sekaligus menjadi momok di dalam suatu perekonomian, namun eksistensinya tetap diperlukan dalam pembangunan, sementara pembangunan ekonomi itu sendiri sangat dipengaruhi oleh pola dan kebijakan ekonomi yang diambil negara tersebut.

Pembentukan harga pada dasarnya adalah hasil kekuatan demand dan supply di pasar, sehingga sering dipandang sebagai hasil jual beli produsen dan konsumen. Inflasi sering diukur dengan Indeks Harga Konsumen (IHK), artinya konsumenlah yang perlu diperhatikan sebagai objek inflasi. Disisi lain terdapat juga Indeks Harga Produsen (IHP), dimana produsen menjadi konsumen terhadap bahan baku yang dibelinya.

Namun yang menarik adalah kita memandang inflasi dari sudut konsumen saja, karena kalau harga naik sudah pasti meresahkan konsumen dan menguntungkan produsen dan sebaliknya. Di pasar yang sering terjadi adalah harga cenderung naik dari waktu kewaktu dan jarang turun, sehingga lebih banyak merugikan konsumen dari pada

\footnotetext{
*Email: afrizal@ekonomi.untan.ac.id

Received: 01 Maret 2018, Accepted : 21 Maret 2018, Published : 18 Agustus 2018

p-ISSN : 2087 - 9954, e-ISSN : 2550 - 0066. DOI : http://dx.doi.org/10.26418/jebik.v7i2.24199
} 
produsen, tetapi bila terjadi deflasi menguntungkankah?. Kondisi ini justru melawan pertumbuhan ekonomi. Dalam perekonomian kedua nya sama-sama tidak mengenakan, dimana deflasi menunjukkan kelesuan dunia usaha, walaupun menguntungkan bagi konsumen tapi tidak bagi produsen, sehingga produsen tidak mampu ekspansi usaha karena tidak ada insentif ekonomi bagi mereka, oleh karena itu peran otoritas moneter dan pemerintah melalui Tim Pengendali Inflasi Daerah (TPID) dituntut untuk menjaga stabilitas harga.

Tingkat inflasi yang stabil tidak dapat tercapai hanya melalui kebijakan moneter saja, tetapi juga harus bersamaan dengan kebijakan fiskal, sektor riil dan kebijakan ekonomi lainnya yang dapat ditempuh Pemerintah. Sehingga dalam penetapan sasaran inflasi, pemantauan serta pengendaliannya harus ada koordinasi antara Pemerintah dan Bank Indonesia sebagai otoritas moneter.

Kebijakan moneter di Indonesia yang masih cukup popular dewasa ini adalah TMT (Tight Money Policy), yang diarahkan untuk menjaga kestabilan harga. Kebijakan tersebut muncul sebagai akibat dari jumlah uang yang beredar dalam perekonomian terlalu banyak, karena dampak dari kondisi ini menyebabkan nilai uang menjadi turun dan tingkat harga akan naik yang dapat menimbulkan inflasi, begitu juga sebaliknya, jika jumlah uang beredar terlalu sedikit dalam perekonomian akan menyebabkan perekonomian menjadi lesu. Oleh karena itu peredaran uang perlu mendapat penjagaan ketat oleh pemerintah.

Kurun waktu 30 tahun pembangunan ekonomi Indonesia cukup berhasil, walaupun sempat mengalami goncangan ekonomi karena krisis moneter di tahun 1997, yang dikenal dengan sebutan krismon, dimana nilai tukar rupiah tergerus sampai mencapai Rp.15.000,-/US \$, dan tingkat inflasi Indonesia mencapai 78\%. Dengan depresiasi rupiah terhadap dollar AS tersebut, menyebabkan harga barang-barang impor menjadi mahal, biaya produksi menjadi tinggi, sehingga barang yang produksi tidak terserap oleh pasar karena naiknya harga-harga barang, akibatnya produsen akan mengurangi produksinya, karena daya beli masyarakat lemah. Sehingga fluktuasi kurs tersebut akan mengakibatkan tingkat harga menjadi tidak stabil.

Mekanisme kebijakan moneter dapat dilakukan melalui jalur suku bunga, perubahan suku bunga dapat mempengaruhi pengeluaran investasi dan konsumsi yang merupakan komponen permintaan agregat. Jika pergerakan suku bunga meningkat maka cost of capital akan naik, dan produsen akan meningkatkan harga barang mereka, yang dalam teori sering disebut sebagai inflasi yang disebabkan oleh kenaikan biaya produksi (cost push inflastion) (Utari, S, \& Pambudi, 2015 : 40). Jadi tingkat suku bunga dapat mempengaruhi tingkat inflasi baik secara langsung maupun tidak.

Begitu pentingnya keberadaan inflasi dalam suatu perekonomian dalam rangka menjaga kestabilan makroekonomi, maka penulis ingin mengidentifikasi dan mengalisis variabel-variabel penting yang dapat menyebabkan fluktuasi inflasi di Indonesia selama kurun waktu tahun $2000-2016$. 
Berdasarkan uraian di atas, maka penelitian ini bertujuan untuk mengeta hui dan menganalisis dampak pengaruh jumlah uang beredar, kurs rupiah terhadap dolar merika, suku bunga terhadap inflasi di Indonesia periode 2010.1-2016.4.

Dengan diketahuinya variabel-variabel yang berpengaruh terhadap inflasi di Indonesia ini diharapkan dapat memberikan gambaran kepada pengambil kebijakan, bahwa tingkat inflasi harus tetap dikawal agar makroekonomi kita tetap stabil, sehingga pertumbuhan ekonomi dapat tercapai. Disamping itu sebagai ajang pembelajaran bagi mahasiswa dalam melihat pentingnya menjaga tingkat harga dalam suatu perekonomian.

\section{KAJIAN LITERATUR}

\subsection{Teori Inflasi}

Inflasi adalah proses kenaikan harga-harga umum secara terus-menerus selama periode tertentu, mempengaruhi individu, pengusaha dan pemerintah. Inflasi secara umum dianggap sebagai masalah penting yang harus diselesaikan dan sering menjadi agenda utama politik dan pengambil kebijakan (Miskhin, 2010 : 13). Biasanya angka inflasi ditunjukkan dengan persentase (Boediono, 2006 : 161).

Keeratan hubungan inflasi dengan jumlah uang beredar tidak dapat dilihat dalam jangka pendek (Mankiw, 2003). Teori inflasi ini bekerja paling baik dalam jangka panjang, bukan dalam jangka pendek. Dengan demikian, hubungan antara pertumbuhan uang dan inflasi dalam data bulanan tidak akan seerat hubungan keduanya jika dilihat selama periode 10-tahun.

Setiap perekonomian pasti mengalami inflasi, yang menjadi pertanyaan kita adalah mengapa inflasi itu terjadi, berbahayakah inflasi tersebut?. Ada beberapa teori yang membahas tentang inflasi antara lain: teori kuantitas, Teori Keynes dan Teori Struktural.

1. Teori Kuantitas dari kaum klasik, berpendapat bahwa tingkat harga ditentukan oleh jumlah uang beredar, harga akan naik jika ada penambahan jumlah uang beredar, dengan asumsi jumlah barang yang ditawarkan tetap, sedangkan jumlah uang ditambah menjadi dua kali lipat, maka cepat atau lambat harga akan naik menjadi dua kali lipat.

2. Teori J.M. Keynes : melihat bahwa inflasi terjadi karena adanya keserakahan dari suatu kelompok masyarakat yang ingin memanfaatkan lebih banyak barang dan jasa yang tersedia. Kondisi ini menyebabkan permintaan agregat meningkat, sedangkan penawaran tetap, yang akan terjadi adalah harga akan naik.

3. Teori Struktural : Teori ini menyorot penyebab inflasi dari segi struktural ekonomi yang kaku. Produsen tidak dapat mengantisipasi cepat kenaikan permintaan yang disebabkan oleh pertambahan penduduk. Permintaan sulit dipenuhi ketika ada kenaikan jumlah penduduk.

Secara grafis mengapa inflasi itu terjadi, dapat kita lihat sebagai berikut:

i. Demand Pull Inflation, yaitu inflasi yang disebabkan oleh meningkatnya jumlah permintaan akan barang dan jasa.

Pada kurva 1 menunjukkan hubungan antara harga barang $(\mathrm{P})$, jumlah yang diminta dan ditawarkan (Q), dan keseimbangan harga (E). Terjadinya Demand 
Pull Inflation ketika permintaan akan barang dan jasa meningkat, maka kurva permintaan total (D) bergeser dari $D_{1} D_{1}$ ke $D_{2} D_{2}$. Ketika itu para pedagang akan mengambil keuntungan dengan menaikkan harga barang dari $\mathrm{P}_{1} \mathrm{ke}_{2} \mathrm{P}_{2}$. Sehingga pada saat itu, terjadi inflasi dan menimbulkan harga keseimbangan baru dari $\mathrm{E}_{1} \mathrm{ke} \mathrm{E}_{2}$.

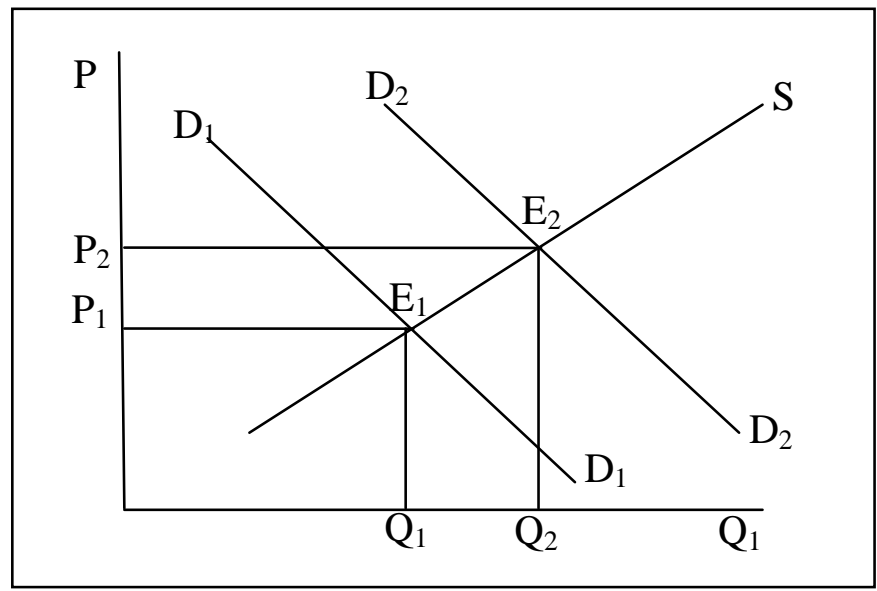

Kurva 1: Demand Pull Inflation

Sumber: Samuelson \& Nordhaus, (2009)

ii. Cost Push Inflation, yaitu inflasi yang disebabkan oleh kenaikan biaya

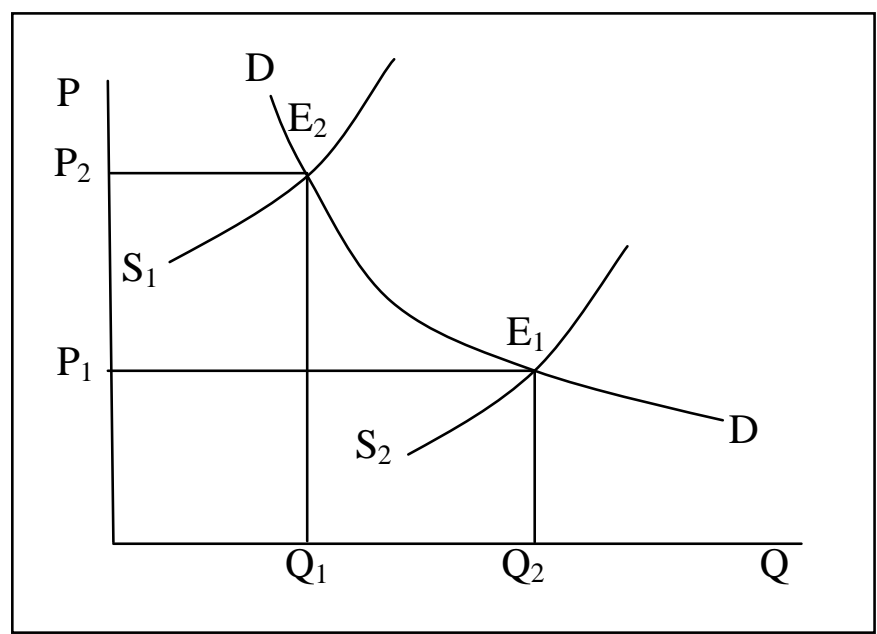

Kurva 2 : Cost Push Inflation

Sumber: Samuelson \& Nordhaus, (2009)

Pada kurva tersebut menunjukkan perilaku produsen ketika menghadapi situasi dimana harga produksi mengalami peningkatan. Jika terjadi kenaikan harga produksi maka produsen akan menaikkan harga dari $\mathrm{P}_{1} \mathrm{ke} \mathrm{P}_{2}$ tetapi dia justru akan menurunkan jumlah barang/jasa yang dihasilkan dari $\mathrm{Q}_{2}$ ke $\mathrm{Q}_{1}$ sehingga akan menggeser kurva penawaran dari $S_{2}$ menjadi $S_{1}$. Hal ini 
dilakukan agar produsen tidak terus merugi sambil menunggu harga produksi kembali turun.

Namun demikian, menurut (Mankiw, 2003), keeratan hubungan inflasi dengan jumlah uang beredar tidak dapat dilihat dalam jangka pendek. Teori inflasi ini bekerja paling baik dalam jangka panjang.

Strategi untuk menjaga kestabilan harga ini terus dilakukan oleh pemerintah melalui kebijakan moneter, instrumen yang sering digunakan oleh otoritas moneter untuk mempengaruhi kondisi makroekonomi yang dilaksanakan melalui pasar uang (Boediono, 2006 : 96) ini adalah pengertian dasar dari kebijakan moneter. Secara khusus, kebijakan moneter bisa diartikan sebagai tindakan yang dilakukan oleh otorita moneter untuk mempengaruhi jumlah uang beredar dan dapat mempengaruhi kegiatan ekonomi suatu negara (Nopirin, $2014: 45$ ).

\subsection{Pergerakan Jumlah Uang Beredar}

Total stok uang dalam suatu kegiatan perekonomian dalam satu periode tertentu yang umumnya satu tahun sering disebut sebagai jumlah uang beredar/jub (money supply). Jumlah uang beredar ini bukanlah hanya uang yang beredar di tangan masyarakat saja, tetapi juga adalah uang yang dikeluarkan secara resmi oleh Bank Sentral maupun bank umum (Pracoyo \& Antyo, 2005 : 139).

Model Klasik tentang uang sering disebut sebagai teori kuantitas, yang mempunyai hubungan dengan tingkat harga absolut yang ditentukan oleh penawaran uang nominal. Teori ini menyimpulkan bahwa tingkat harga merupakan akibat utama adanya perubahan jumlah uang beredar (Mankiw, 2006 : 114).

Teori Keynes dalam (Nopirin, 2014 : 94), bahwa Keynes tidak melihat jumlah uang beredar merupakan faktor eksogen dalam kegiatan suatu perekonomian. Menurut Keynes, uang beredar sebagai faktor yang sangat ditentukan oleh kegiatan ekonomi suatu masyarakat. Jadi menurut Keynes besarnya angka pelipat uang dipengaruhi oleh kegiatan ekonomi.

Disampng itu menurut pandangan kaum Monetaris, bahwa perubahan jumlah uang beredar tidak terpengaruh oleh kegiatan ekonomi, Sehingga jumlah uang beredar merupakan faktor eksogen (Nopirin, 2014 : 94). Konsep ini berbeda dengan pandangan Keynes. Sehingga kaum moneteris, Milton Friedman menganggap bahwa uang beredar sangat mempengaruhi dan berperan aktif dalam kegiatan ekonomi suatu masyarakat.

Dalam pengertian sempit jumlah uang beredar adalah uang kertas dan logam yang ada ditangan masyarakat. Dornbusch \& Fischer, (1994) memberi definisi jumlah uang bredar sebagai berikut :

$$
\begin{aligned}
& \mathrm{M} 1=\mathrm{C}+\mathrm{DD} \\
& \mathrm{M} 2=\mathrm{M} 1+\mathrm{TD}+\mathrm{SD}
\end{aligned}
$$

dimana $\mathrm{C}$ adalah uang kartal (currency), DD adalah uang giral (demand deposit), TD adalah deposito berjangka (time deposit), dan SD adalah saldo tabungan (saving deposit).

Dari definisi di atas menunjukkan bahwa simpanan dan tabungan berjangka (saving and demand deposit) tidak dimasukkan dalam jumlah uang beredar, karena keduanya 
bukan merupakan uang nyata (actual money) meski dapat sebagai pengukur nilai (store of value) dan merupakan uang potensial.

\subsection{Volatile Kurs}

Volatile, yaitu apabila kurs tersebut sangat peka untuk bergerak, disini harga valuta asing mudah sekali berfluktuasi dan sangat tergantung pada kondisi perekonomian. Nilai tukar atau sering disebut kurs adalah harga mata uang negara asing dalam satuan mata uang domestik. Penentuan nilai tukar ini berdasarkan kesamaan tingkat bunga atau dikenal dengan interest rate parity theory, yang menyatakan bahwa dalam pasar persaingan sempurna biaya yang harus dibayar untuk memperoleh sejumlah dana tercermin dari perbedaan tingkat bunga di kedua negara, dana akan cenderung mengalir dari negara yang tingkat bunganya rendah ke negara lain yang tingkat bunganya lebih tinggi.

Kurva penawaran valuta asing berasal dari permintaan suatu negara akan impor. Hal ini disebabkan karena di saat negara membayar hutang atas impornya dalam kurs luar negeri, maka penerima di dalam negeri harus menjual kursnya untuk mendapatkan kurs luar negeri, Dan sebaliknya, apabila impor didasarkan kurs domestik, maka penerima luar negeri harus menjual kursnya.

Permintaan suatu negara akan impor menyebabkan permintaan valuta asing meningkat, sehingga nilai mata uang domestik dapat melemah, hal ini menyebabkan harga barang yang kita beli di luar negeri menjadi lebih mahal, yang pada giliriannya biaya produksi pun meningkat, kondisi ini dapat menyebabkan inflasi di dalam negeri (import inflation).

\subsection{Peran Suku Bunga}

Hubungan inflasi dan suku bunga sering diungkapkan dalam teori ekonomi makro. Inflasi merujuk pada tingkat kenaikan harga barang dan jasa, sedangkan suku bunga di Indonesia merujuk pada tingkat suku bunga yang diatur oleh Bank Indonesia, dikenal sebagai BI Rate, tetapi sejak 19 Agustus 2016 suku bunga acuan menggunakan data suku bunga repo 7 hari BI (7-Day BI Repo Rate).

Berdasarkan data empiris, tingkat inflasi selalu lebih tinggi dari suku bunga, akibatnya daya beli dari uang penabung atau deposan mengalami penurunan meskipun secara absolut jumlah uangnya bertambah dengan adanya tambahan dari bunga yang diterimanya, hal ini menunjukkan bahwa bunga tidak membuat orang lebih kaya jika uangnya ditabung atau didepositokan, tetapi malah sebaliknya, (Amir, 2008). Kondisi ini menunjukkan bahwa inflasi menimbulkan biaya. Jika inflasi menimbulkan biaya, maka bunga juga menimbulkan biaya. Biaya uang yaitu suku bunga (interest) ditimbulkan oleh inflasi (Mankiw, 2007).

Ketika suku bunga rendah, pengaruh yang timbul adalah makin banyak orang meminjam uang. Akibatnya konsumsi bertambah karena uang beredar lebih banyak, ekonomi mulai tumbuh, dan efek lanjutannya adalah inflasi naik. Dampak sebaliknya juga berlaku, jika suku bunga tinggi, peminjam uang makin sedikit, sehingga lebih 
banyak orang menahan belanja, mereka memilih menabung. Yang terjadi tingkat konsumsi turun. Inflasi pun turun.

\subsection{Penelitian sebelumnya}

Penelitian mengenai inflasi sudah cukup banyak dilakukan, antara lain pernah dilakukan oleh Dumairy, (1987) dan Jamin, (1990), yang melakukan pengujian terhadap kausalitas antara jumlah uang beredar dan tingkat inflasi di Indonesia. Dengan menggunakan data kwartalan, hasil yang diperoleh secara statistik menunjukkan bahwa jumlah uang beredar mempunyai pengaruh signifikan pada inflasi. Dalam penelitian tersebut Dumairy hanya melakukan uji Grangger. Sedangkan Janin M.A. menggunakan uji Sims, dengan data kwartalan, diperoleh kesimpulan bahwa jumlah uang beredar mempunyai pengaruh signifikan pada inflasi.

Sriyana, (2001) dengan pendekatan model ECM menggungkapkan bahwa inflasi di Indonesia berkaitan dengan jumlah uang beredar dan ekspansi fiskal, peningkatan jumlah uang beredar satu milyar rupiah akan berpengaruh terhadap peningkatan inflasi sebesar 2,49\% dan dalam jangka panjang berpengaruh terhadap peningkatan inflasi 23,33\%. Sedangkan nilai tukar dalam jangka pendek tidak secara signifikan mempengaruhi kenaikan inflasi, namun tidak begitu dalam jangka panjang.

Ramakrishnan \& Vamvakidis, (2002) dengan menggunakan data time series tahun 1980-2000 dalam penelitiannya di Indonesia, menemukan bahwa secara statistik perubahan nilai tukar secara statistik berpengaruh signifikan terhadap inflasi. Jika rupiah terdepresiasi $1 \%$ maka akan meningkatkan inflasi 0,3\%. Demikian pula dengan jub, jika jub naik 1 persen akan mengakibatkan kenaikan inflasi 0,04 persen. Sementara itu perubahan upah minimum, produktivitas dan tingkat suku bunga tidak memberikan pengaruh yang signifikan terhadap inflasi.

Widiastuti, (2012), meneliti tentang Pengaruh Jumlah Uang Beredar terhadap Inflasi di Indonesia, data bulanan periode Januari 2001-Desember 2011, model yang digunakan Error Correction Models (ECM). Temuannya adalah 1). Dalam jangka pendek jumlah uang beredar tidak berpengaruh atau tidak signifikan terhadap laju inflasi di Indonesia, tetapi inflasi pada bulan tersebut dipengaruhi oleh jumlah uang beredar pada bulan sebelumnya. 2). Dalam jangka panjang panjang jumlah uang beredar tidak berpengaruh atau tidak signifikan terhadap inflasi.

Putra \& Meydianawati, (2014), melakukan penelitian yang berjudul Vector Auto Regressive Terhadap Kausalitas Inflasi dan Jumlah Uang Beredar di Indonesia. Hasil pengujian menunjukkan bahwa Hubungan kausalitas antara tingkat Inflasi dan jumlah uang beredar di Indonesia tidak terdapat hubungan dalam periode penelitian tersebut.

\subsection{Kerangka Pemikiran}

Berdasarkan penjelasan latar belakang dan tujuan penelitian tersebut di atas maka kerangka pemikiran dalam penelitian ini digambarkan dalam Gambar 1. Kerangka pemikiran tersebut menunjukkan bahwa ketidakstabilan jumlah uang beredar, volatile kurs rupiah terhadap dollar AS dan pergerakan suku bunga sangat berpengaruh terhadap tingkat inflasi di Indonesia 


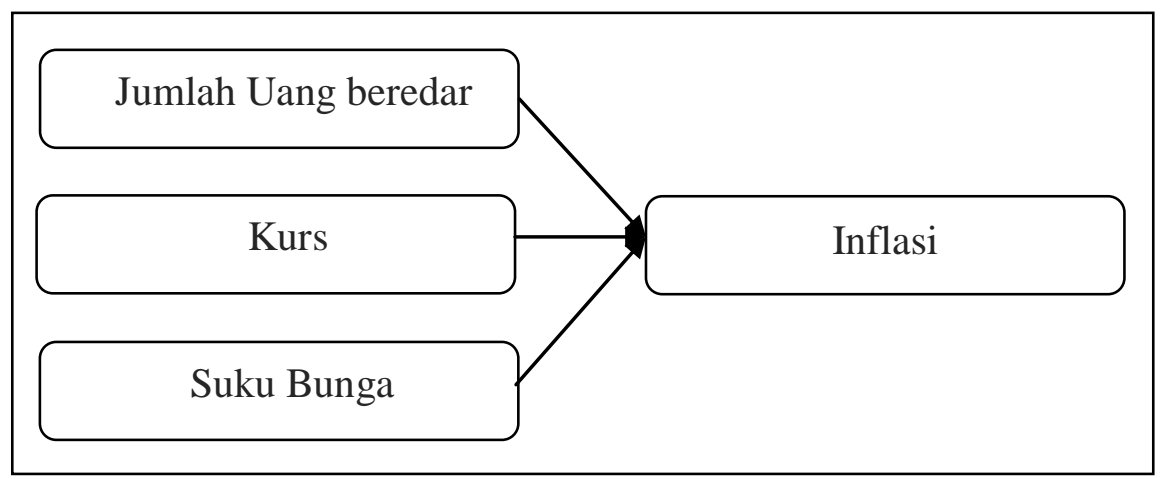

\subsection{Hipotesis Penelitian}

\section{Gambar 1. Kerangka Pemikiran}

Berdasarkan landasan teori dan kajian empiris tersebut di atas, maka dapat dibentuk hipoteisis penelitian sebagai berikut: "diduga bahwa jumlah uang beredar, kurs Rupiah terhadap Dollar Amerika dan suku bunga berpengaruh positif dan signifikan terhadap inflasi di Indonesia".

\section{METODA PENELITIAN}

\subsection{Jenis dan Data Penelitian}

Penelitian ini menggunakan pendekatan kuntitatif, yaitu berusaha menjelaskan hubungan satu variabel dengan variabel yang lain dengan menggunakan metode kuadrat terkecil biasa (ordinary least square), hal ini banyak dituntut dalam menjelaskan angka, mulai dari teknis pengumpulan data, jenis data, penafsiran terhadap data serta hasilnya. Data yang digunakan dalam penlitian ini adalah data kuartalan dalam bentuk time series, yang terdiri dari data tingkat inflasi, jumlah uang beredar (m2), nilai tukar rupiah (kurs) dan suku bunga selama kurun waktu 2010 sampai dengan Desember 2016.

Data bersumber dari website Otorisasi Jasa Keuangan (www.ojk.go.id), Bank Indoenesia (www.bi.go.id), Badan Pusat Statistik (www.bps.go.id) dan sumber-sumber lain yang berkaitan dengan penelitian ini.

\subsection{Model Analisis}

Program pengolahan data yang digunakan dalam penelitian ini adalah menggunakan program olah data Eviews 9.0. Sebelum dilakukan estimasi model, data time series yang digunakan diuji validitasnya atau kestabilannya melalui uji akar-akar unit untuk menghindari spurious regression (semu), uji tersebut dikenal dengan uji Dickey-Fuller (DF) dan uji Augmented Dickey-Fuller (ADF) (Dickey \& Fuller, 1979). Selanjutnya dilakukan uji derajad integrasi (integration degree test) yang bertujuan pada derajad berapa variabel-variabel yang diamati akan stationer. Apabila semua variabel lolos dari 
uji akar-akar unit dan derajat integrasi, maka selanjutnya dilakukan uji kointegrasi (cointegration test) untuk mengetahui kemungkinan terjadinya keseimbangan atau kestabilan jangka panjang antara variabel-variabel yang diteliti. Setelah dilakukan uji kointergrasi, model inflasi ini akan diuji kestabilannya dengan pendekatan Error Correction Model (ECM) yang dikembangkan oleh (Eagle \& Granger, 1987). Penggunaan ECM ini adalah untuk mengetahui kemungkinan terjadinya perubahan struktural. Hal ini karena keseimbangan jangka panjang antara variabel bebas dan terikat merupakan hasil uji kointegrasi tidak akan berlaku setiap saat atau periode. Oleh karena error-term yang terdapat dalam persamaan Error Correction Model (ECM) harus diperlakukan sebagai suatu keseimbangan kesalahan pengganggu (equilibrium-term) dalam jangka panjang.

\subsection{Spesifikasi Model}

Pada penelitian ini penulis mengembangkan spesifikasi model dinamik dengan menelusuri pengaruh Jumlah Uang Beredar (jub), Kurs (k), Suku bunga (r), terhadap Inflasi (if) di Indonesia kurun waktu tahun 2000.1-20016.4. Sebelum melakukan estimasi Error Correction Model (ECM), maka dilakukan uji sebagai berikut:

\section{Uji Stasioner (unit root test)}

Dalam berbagai studi ekonometrika, data time series sering digunakan, namun data tersebut ternyata menyimpan berbagai permasalahan yaitu otokorelasi (Nachrowi \& Usman, 2006 : 340). Otokorelasi merupakan penyebab yang mengakibatkan data tidak stasioner, yaitu data yang menunjukkan mean, varians, dan autovarians (pada variabel lag) tidak konstan pada saat data tersebut digunakan, sehingga hubungan yang spurious (semu) diantara variabel-variabel yang diamati, untuk itu digunakanlah uji stasioneritas dengan menggunakan uji unit root Dickey-Fuller dalam Thomas, (1995 : 416). Jika di dalam pengujian tersebut ternyata data sudah stasioner, maka pengujian dapat dilanjutkan ke pada data asli. Tapi jika salah satu variabel ada yang tidak stasioner pada orde nol, I(0), maka maka stasioner data tersebut dapat dicari melalui order berikutnya sehingga diperoleh tingkat stasioner pada order ke $\mathrm{n}$ (first difference atau $\mathrm{I}(1)$, atau second difference atau I(2), dan seterusnya.

Proses yang dilakukan untuk pengujian akar-akar unit ini adalah menaksir model otoregresif dari masing-masing variabel sebagai berikut:

$$
\begin{aligned}
& D X_{t}=a_{0}+a_{1} B X_{t} \sum_{i+1}^{k} b_{i} B^{i} D X_{t} \\
& D X_{t}=c_{0}+c_{1} T+c B X_{t}+\sum_{i=1}^{k} d_{i} B^{i} D X_{t}
\end{aligned}
$$

di mana $\mathrm{DX}_{\mathrm{t}}=\mathrm{x}_{\mathrm{t}}-\mathrm{x}_{\mathrm{t}-1}, \mathrm{BX}_{\mathrm{t}}=\mathrm{X}_{\mathrm{t}-1}, \mathrm{~T}=$ Trend waktu dan $\mathrm{X}_{\mathrm{t}}=$ variabel yang diamati pada periode $\mathrm{t}$ serta $\mathrm{B}$ adalah operasi kelambanan waktu ke udik (backward lag operator). 


\section{Uji Derajat Integrasi}

Regresi lancung umumnya disebabkan oleh data yang digunakan tidak stasioner, maka harus mentransformasikan data yang tidak stasioner menjadi data stasioner. Pada penelitian ini menggunakan metode transformasi uji akar unit Philips-Perron (PP) Widarjono, (2009). Adapun formulasi uji derajat integrasi dari PP sebagai berikut :

$$
\begin{aligned}
& \Delta 2 \mathrm{Y}_{\mathrm{t}}=\gamma \Delta \mathrm{Y}_{\mathrm{t}-1}+\mathrm{e}_{\mathrm{t}} \\
& \Delta 2 \mathrm{Y}_{\mathrm{t}}=\mathrm{a}_{0}+\gamma \Delta \mathrm{Y}_{\mathrm{t}-1}+\mathrm{e}_{\mathrm{t}} \\
& \Delta 2 \mathrm{Y}_{\mathrm{t}}=\mathrm{a}_{0}+\mathrm{a}_{1} \mathrm{~T}+\gamma \Delta \mathrm{Y}_{\mathrm{t}-1}+\mathrm{e}_{\mathrm{t}}
\end{aligned}
$$

Dimana: $\Delta 2 \mathrm{Y}_{\mathrm{t}}=\Delta \mathrm{Y}_{\mathrm{t}}-\Delta \mathrm{Y}_{\mathrm{t}-1}$

Seperti uji akar unit sebelumnya, keputusan sampai pada derajat keberapa suatu data akan stasioner dapat dilihat dengan membandingkan antara nilai statistik PP yang diperoleh dari koefisien $\gamma$ dengan nilai kritis distribusi statistik Mackinnon. Jika nilai absolut dari statistik PP lebih besar dari nilai kritisnya pada diferensi tingkat pertama, maka data dikatakan stasioner pada derajat satu. Akan tetapi, jika nilainya lebih kecil maka uji derajat integrasi perlu dilanjutkan pada diferensi yang lebih tinggi sehingga diperoleh data yang stasioner Widarjono, (2009).

Hipotesis :

$$
\begin{aligned}
& \mathrm{H}_{0}=\text { Data tersebut tidak stationer pada derajat } 1 \\
& \mathrm{H}_{1}=\text { Data tersebut stationer pada derajat } 1
\end{aligned}
$$

Kriteria:

Jika PP t-statistik > PP kritis statistik (critical value $\alpha=5 \%$ ) maka $\mathrm{H}_{0}$ ditolak.

Jika PP t-statistik < PP kritis statistik (critical value $\alpha=5 \%$ ) maka $\mathrm{H}_{0}$ diterima.

\section{Uji Kointergrasi (Johansen)}

Sering dijumpai bahwa dua variabel random yang masing-masing merupakan random walk (tidak stasioner), tetapi kombinasi linier antara dua variabel tersebut merupakan time series yang stasioner. Dalam penelitian ini yang digunakan adalah uji yang dikembangkan Johansen untuk menentukan kointegrasi sejumlah variabel (vektor). Jika variabel gangguan ternyata tidak mengandung akar unit atau dikatakan data stasioner maka variabel yang diteliti adalah terkointegrasi yang berarti mempunyai hubungan jangka panjang. Kointegrasi hanya bisa dilakukan ketika data yang digunakan dalam penelitian berintegrasi pada derajat yang sama (Widarjono, 2009). Prosesnya pengujian sebagai berikut: 


\section{Hipotesis :}

$\mathrm{H}_{0}=$ Tidak terdapat hubungan jangka panjang antara variabel independen dan variabel dependen.

$\mathrm{H}_{1}=$ Terdapat hubungan jangka panjang antara variabel independen dan variabel dependen.

Kriteria :

Jika nilai trace statistic > nilai critical value maka $\mathrm{H}_{0}$ ditolak

Jika nilai trace statistic < nilai critical value maka $\mathrm{H}_{0}$ diterima

\section{Model Koreksi Kesalahan (Error Correction Model/ECM)}

Analisis yang digunakan dalam penelitian ini adalah analisis deskriptif kuantitatif dengan mengestimasi secara kuantitatif dampak dari beberapa variabel penjelas baik secara simultan maupun parsial terhadap variabel terikat. Untuk mengetahui dampak tersebut penulis menggunakan multiple regression model dinamik dengan pendekatan Error Correction Model (ECM). Pendekatan ini menghiasi wajah ekonometrika untuk analisis data time series sejak tahun 1960-an yang dikenalkan oleh Prof. Sargen, guru besar London School of Economics, Inggris. Pendekatan ini diyakini dapat menguji apakah spesifikasi model empirik yang digunakan valid atau tidak berdasarkan nilai keofisien Error Correction Term, dan mengkaji konsistensi tidaknya model empirik dengan teori ekonomi (Insukendro, $1993: 2$ ).

Pembentukan model koreksi kesalahan (Error Correction Model/ECM), diawali dengan persamaan dasar model inflasi Indonesia, yaitu:

$$
\mathrm{if}_{\mathrm{t}}=\beta_{0}+\beta_{1} \mathrm{jub} \mathrm{b}_{\mathrm{t}}+\beta_{2} \mathrm{k}_{\mathrm{t}}+\beta_{3} \mathrm{er}_{\mathrm{t}}
$$

Keterangan :

if $_{\mathrm{t}} \quad=$ Tingkat Inflasi pada periode $\mathrm{t}$ (dalam persen)

jub $_{\mathrm{t}}=$ Jumlah Uang Beredar/M2 periode $\mathrm{t}$ (Dalam Miliar Rupiah)

$\mathrm{k}_{\mathrm{t}} \quad=$ Nilai Tukar Rupiah terhadap Dollar/kurs (dalam Rupiah)

$\mathrm{r}_{\mathrm{t}} \quad=$ Suku bunga pada periode $\mathrm{t}$ (dalam persen)

$\mathrm{t} \quad=$ periode waktu

Kemudian dari model tersebut di atas dibentuk fungsi biaya kuadrat tunggal (single periode quadratic cost function), yang dikembangkan oleh Domowitz dan ElBadawi (1987) dalam Widarjono, (2009), dengan terlebih dahulu melakukan minimisasi terhadap fungsi biaya kuadrat tunggal, sehingga akan diperoleh bentuk empirik model koreksi kesalahan sebagai berikut : 


$$
\begin{gathered}
\mathrm{DBLif}_{\mathrm{t}}=\beta_{0}+\beta_{1} \mathrm{DBLjub}_{\mathrm{t}}+\beta_{2} \mathrm{DBLk}_{\mathrm{t}}+\beta_{3} \mathrm{DBLr}_{\mathrm{t}}+\beta_{4} \mathrm{BLjub}_{\mathrm{t}}+ \\
\beta_{5} \mathrm{BLk}_{\mathrm{t}}+\beta_{6} \mathrm{BLr}_{\mathrm{t}}+\beta_{7} \mathrm{ECT}
\end{gathered}
$$

dimana

B adalah lag operasi kelambanan ke udik,

D adalah perubahan

$$
\begin{array}{ll}
\text { DBLif }_{\mathrm{t}} & =\mathrm{if}_{\mathrm{t}}-\text { Bif }_{\mathrm{t}} \\
\text { DBLjub }_{\mathrm{t}} & =\mathrm{jub}_{\mathrm{t}}-\mathrm{Bjub}_{\mathrm{t}} \\
\text { DBLk }_{\mathrm{t}} & =\mathrm{k}_{\mathrm{t}}-\mathrm{Bk}_{\mathrm{t}} \\
\text { DBLr }_{\mathrm{t}} & =\mathrm{r}_{\mathrm{t}}-\mathrm{Br}_{\mathrm{t}} \\
\text { BLjub }_{\mathrm{t}} & =\mathrm{jub}_{\mathrm{t}}-\mathrm{jub} \mathrm{t}-1 \\
\text { BLk }_{\mathrm{t}} & =\mathrm{k}_{\mathrm{t}}-\mathrm{k}_{\mathrm{t}-1} \\
\text { BLr }_{\mathrm{t}} & =\mathrm{r}_{\mathrm{t}}-\mathrm{r}_{\mathrm{t}-1} \\
\mathrm{ECT} & =\text { Error Correction Term }\left(j u b_{\mathrm{t}-1}+\mathrm{k}_{\mathrm{t}-1}+\mathrm{r}_{\mathrm{t}-1}-\mathrm{if}_{\mathrm{t}-1}\right)
\end{array}
$$

Dari persamaan tersebut di atas akan dapat diketahui konsistensi hasil estimasi model koreksi kesalahan dengan teori ekonomi. Kemudian dapat juga diestimasi koefisien regresi jangka panjang model yang sedang dianalisis dan penentuan bentuk fungsi model empirik yang digunakan (Insukindro \& Aliman, 1999 : 50-61).

\section{HASIL PENELITIAN DAN PEMBAHASAN}

\subsection{Hasil Uji Akar-Akar Unit (unit root test)}

Sebelum melakukan analisis data penelitian tentang variabel yang mempengaruhi inflasi di Indonesia, terlebih dahulu dilakukan uji akar-akar unit (unit roots test) yang bertujuan untuk membuat sebuah struktur data penelitian tersebut stasioner, artinya semua variabel penelitian telah stasioner. Uji ini dilakukan sesungguhnya adalah untuk supaya data yang akan digunakan memiliki fluktuasi data yang rendah, sehingga membuat hasil estimasi yang dilakukan memiliki varian yang rendah juga.

Berdasarkan uji akar-akar unit (unit roots test) menunjukkan bahwa diperoleh hasil sebagai berikut:

Tabel 1. Hasil Uji Akar-Akar Unit (unit roots test) pada tingkat level

\begin{tabular}{cccc}
\hline Variabel & Nilai Statistik & Taraf Signifikan & Kesimpulan \\
\hline If & 0.0872 & 0,05 & Tidak Stasioner \\
\hline jub & 0.9936 & 0,05 & Tidak Stasioner \\
\hline $\mathrm{k}$ & 0.2655 & 0,05 & Tidak Stasioner \\
\hline $\mathrm{r}$ & 0.1682 & 0,05 & Tidak Stasioner \\
\hline
\end{tabular}


Berdasarkan Tabel 1, menunjukkan bahwa semua data belum stasioner pada tingkat level dengan panjang lag $=4$, karena nilai probability lebih besar dari taraf signifikan $5 \%$. Oleh karena semua variabel tidak stasioner pada tingkat level, maka dilanjutkan dengan uji derajat integrasi pertama.

Untuk mendapatkan data stasioner perlu dilakukan uji akar-akar unit yang lebih tinggi, yaitu pada level satu (first difference), sebagai berikut:

Tabel 2. Hasil Uji Akar-Akar Unit (unit roots test) pada level 1.

\begin{tabular}{cccc}
\hline Variabel & Nilai Statistik & Taraf Signifikan & \multicolumn{1}{c}{ Kesimpulan } \\
\hline if & 0.0000 & 0,05 & Stasioner \\
\hline jub & 0.0000 & 0,05 & Stasioner \\
\hline $\mathrm{k}$ & 0.0000 & 0,05 & Stasioner \\
\hline $\mathrm{r}$ & 0.0052 & 0,05 & Stasioner \\
\hline
\end{tabular}

Berdasarkan uji derajad integrasi dengan menggunakan uji akar-akar unit pada level satu (first difference), seperti terlihat pada Tabel 2, data penelitian telah mencapai keadaan yang stasioner karena nilai probability lebih kecil dari taraf signifikan 5\%.

Selanjutnya diteruskan dengan Uji Kointegrasi Johansen, tujuannya adalah untuk melihat jangka panjang dari model tersebut.

\subsection{Uji Kointergrasi Johansen}

Data yang sudah stasioner dapat dilanjutkan uji kointegrasi yang dikembangkan Johansen untuk menentukan kointegrasi sejumlah variabel (vektor). Jika variabel gangguan ternyata tidak mengandung akar unit atau dikatakan data stasioner maka variabel yang diteliti adalah terkointegrasi yang berarti mempunyai hubungan jangka panjang. Hasil pengujian kointegrasi dapat dilihat pada Tabel 3 berikut ini:

Tabel 3: Hasil Estimasi Uji Kointegrasi

\begin{tabular}{|c|c|c|c|c|}
\hline \multicolumn{5}{|c|}{ Unrestricted Cointegration Rank Test (Trace) } \\
\hline Hypothesized & & Trace & 0.05 & \\
\hline No. of CE(s) & Eigenvalue & Statistic & Critical Value & Prob.** \\
\hline None * & 0.393392 & 64.55135 & 55.24578 & 0.0061 \\
\hline At most 1 & 0.270212 & 32.05966 & 35.01090 & 0.1001 \\
\hline At most 2 & 0.119789 & 11.58455 & 18.39771 & 0.3409 \\
\hline At most 3 & 0.049370 & 3.291002 & 3.841466 & 0.0697 \\
\hline \multicolumn{5}{|c|}{ Trace test indicates 1 cointegrating eqn $(\mathrm{s})$ at the 0.05 level } \\
\hline \multicolumn{5}{|c|}{$*$ denotes rejection of the hypothesis at the 0.05 level } \\
\hline \multicolumn{5}{|c|}{ **MacKinnon-Haug-Michelis (1999) p-values } \\
\hline \multicolumn{5}{|c|}{ Unrestricted Cointegration Rank Test (Maximum Eigenvalue) } \\
\hline Hypothesized & & Max-Eigen & 0.05 & \\
\hline No. of CE(s) & Eigenvalue & Statistic & Critical Value & Prob.** \\
\hline None * & 0.393392 & 32.49169 & 30.81507 & 0.0309 \\
\hline At most 1 & 0.270212 & 20.47511 & 24.25202 & 0.1463 \\
\hline At most 2 & 0.119789 & 8.293551 & 17.14769 & 0.5708 \\
\hline At most 3 & 0.049370 & 3.291002 & 3.841466 & 0.0697 \\
\hline
\end{tabular}


* denotes rejection of the hypothesis at the 0.05 level

**MacKinnon-Haug-Michelis (1999) p-values

Berdasarkan Tabel 4 diperoleh bahwa nilai trace statistic sebesar $64.55135>$ critical value sebesar 55.24578, begitu juga dengan nilai max eige stat sebesar $32.49169>$ 30.81507. ini berarti bahwa variabel yang sedang diamati dalam penelitian ini saling berkointegrasi atau memiliki hubungan jangka panjang.

\subsection{Hasil Uji Error Corection Model/ECM}

Regresi estimasi Error Correction Model/ECM dilakukan dengan menggunakan persamaan berikut:

$$
\begin{aligned}
\operatorname{DBLif}_{\mathrm{t}}= & \beta_{0}+\beta_{1} \mathrm{DBLjub}_{\mathrm{t}}+\beta_{2} \mathrm{DBLk}_{\mathrm{t}}+\beta_{3} \mathrm{DBLr}_{\mathrm{t}}+\beta_{4} \mathrm{BLjub}_{\mathrm{t}}+ \\
& \beta_{5} \mathrm{BL} \mathrm{k} \mathrm{k}_{\mathrm{t}}+\beta_{6} \mathrm{BLr}_{\mathrm{t}}+\beta_{7} \text { ECT. }
\end{aligned}
$$

Berdasarkan hasil estimasi persamaan ECM jangka pendek dapat dilihat pada table 4 berikut ini:

\begin{tabular}{|c|c|c|c|c|}
\hline \multicolumn{5}{|c|}{ Dependent Variable: DBLif } \\
\hline \multicolumn{5}{|c|}{ Sample (adjusted): 2000Q2 2016Q4 } \\
\hline \multicolumn{5}{|c|}{ Included observations: 67 after adjustments } \\
\hline Variable & Coefficient & Std. Error & t-Statistic & Prob. \\
\hline $\mathrm{C}$ & 4.007605 & 1.833978 & 2.185198 & 0.0329 \\
\hline DBLjub & -0.004951 & 0.016480 & -0.300444 & 0.7649 \\
\hline DBLk & 0.122503 & 0.274206 & 0.446756 & 0.6567 \\
\hline DBLr & 1.259088 & 0.336756 & 3.738871 & 0.0004 \\
\hline BLjub & -0.368654 & 0.109359 & -3.371046 & 0.0013 \\
\hline BLk & -0.763765 & 0.230394 & -3.315033 & 0.0016 \\
\hline BLr & -0.198177 & 0.105146 & -1.884788 & 0.0644 \\
\hline ECT & 0.366356 & 0.107435 & 3.410012 & 0.0012 \\
\hline$\underline{\mathrm{R} \text {-squared }}$ & 0.316675 & Mean dependent var & & -0.016867 \\
\hline Adjusted R-squared & 0.235603 & S.D. dependent var & & 0.268523 \\
\hline$\underline{\text { S.E. of regression }}$ & 0.234769 & Akaike info criterion & & 0.051223 \\
\hline Sum squared resid & 3.251878 & Schwarz criterion & & 0.314470 \\
\hline Log likelihood & 6.284027 & Hannan-Quinn criter. & & 0.155391 \\
\hline F-statistic & 3.906076 & Durbin-Watson stat & & 2.031110 \\
\hline Prob(F-statistic) & 0.001465 & & & \\
\hline
\end{tabular}

Tabel 4 : Estimasi Error Correction Model Jangka Pendek

Berdasarkan persamaan tersebut di atas bahwa nilai statistik-t pada variabel penjelas Error Correction Term/ECT adalah signifikan dengan nilai sebesar 3,41 artinya spesifikasi model yang digunakan dalam penelitian ini sudah valid, sehingga mengindikasikan adanya kemungkinan hubungan jangka pendek dan jangka panjang terhadap variabel yang diteliti. 
Berdasarkan hasil Estimasi persamaan Error Correction Model tersebut di atas, maka dapat dicari koefisien jangka panjang (Widarjono, 2009) sebagai berikut :

$$
\begin{array}{ll}
\text { Konstanta } & =\left(\beta_{0} / \beta_{7}\right) \\
\text { BLer } & =\left(\beta_{4}+\beta_{7}\right) / \beta_{7} \\
\text { BLjub } & =\left(\beta_{5}+\beta_{7}\right) / \beta_{7} \\
\text { BLr } & =\left(\beta_{6}+\beta_{7}\right) / \beta_{7}
\end{array}
$$

Berdasarkan rumus tersebut maka dapat dihitung koefisien jangka panjang, sehingga diperoleh hasil seperti terlihat pada table 5 .

Tabel 5 : Hasil Estimasi ECM Jangka Panjang

\begin{tabular}{cccc}
\hline Variabel & Coefisient & T-statistik & Prob. \\
\hline $\mathrm{C}$ & 10,9391 & 2.185198 & 0.0329 \\
\hline BLJub $_{\mathrm{t}}$ & 0,631 & -3.371046 & 0.0013 \\
\hline $\mathrm{BLk}_{\mathrm{t}}$ & 0,236 & -3.315033 & 0.0016 \\
\hline $\mathrm{BLr}_{\mathrm{t}}$ & 0,801 & -1.884788 & 0.0644 \\
\hline
\end{tabular}

Hasil Estimasi tersebut di atas dapat ditulis persamaan regresi ECM jangka panjang sebagai berikut:

$$
\begin{aligned}
\operatorname{DBLif}_{\mathrm{t}}= & 10,939-0,0049 \mathrm{DBLjub}_{\mathrm{t}}+0,122 \mathrm{DBLk}_{\mathrm{t}}+1,259 \mathrm{DBLr}_{\mathrm{t}} \\
& +0,631 \mathrm{BLjub}_{\mathrm{t}}+0,236 \mathrm{BLk}_{\mathrm{t}}+0,801 \mathrm{BLr}_{\mathrm{t}}+0,366 \mathrm{ECT}
\end{aligned}
$$

Konstanta (C) yang diperoleh adalah sebesar 4.007, kondisi ini menunjukkan bahwa terjadi perubahan tingkat harga atau inflasi sebesar 10,9391 unit apabila semua variabel penjelas bernilai nol.

Variabel Jumlah Uang Beredar (DBLjub) dalam penelitian ini tidak signifikan, keadaan ini menunjukkan bahwa perubahan variabel jumlah uang beredar (DBLjub) dalam jangka pendek tidak mampu menjelaskan variasi perubahan tingkat inflasi (DBLif) di Indonesia selama kurun waktu periode penelitian. Hasil ini sejalan dengan penelitian yang dilakukan oleh Widiastuti, Irene Linda (2012), namun dalam jangka panjang variabel jumlah uang beredar (BLjub) berpengaruh positif dan signifikan terhadap inflasi (DBLif) di Indonesia, dengan nilai koefisien sebesar 0,631. Artinya jika jumlah uang beredar naik $1 \%$ maka infllasi akan turun sebesar 0,631, hasil ini sesuai dengan teori dan hipotesis yang diajukan, namun berbeda penelitian yang dilakukan Ramakrishnan Dan Vamvakidis (2002) dengan menggunakan data time series tahun 1980-2000. 
Variabel Nilai Tukar (DBLk) dalam jangka pendek tidak berpengaruh terhadap perubahan tingkat inflasi (DBLif) di Indonesia selama kurun waktu penelitian ini, Hasil ini sesuai dengan penelitian yang dilakukan oleh Sriyana (2001) dengan pendekatan model ECM. Dalam jangka panjang variabel nilai tukar berpengaruh signifikan dan positif terhadap tingkat inflasi, dengan nilai koefisien sebesar 0,236 , artinya jika nilai tukar depresiasi $1 \%$ akan menyebabkan tingkat inflasi meningkat sebesar 0,236.

Selanjutnya variabel Suku Bunga deposito (DBLr) dalam jangka pendek tidak signifikan, hal ini menunjukkan bahwa variabel perubahan suku bunga (DBLr) tidak berpengaruh terhadap variasi perubahan tingkat inflasi (DBLif). Namun dalam jangka panjang variabel suku bunga berpengaruh signifikan dan positif terhadap variasi perubahan tingkat inflasi Indonesia, dengan koefisien sebesar 0,801, yang berarti bahwa jika kenaikan suku bunga 1 persen akan menyebabkan terjadi inflasi sebesar $0,801 \%$. Hasil ini tidak sesuai dengan teori dan hipotesis yang dibangunan dalam penelitian ini, seharusnya setiap terjadi peningkatan suku bunga deposito (simpanan), ada kecenderungan masyarakat tertarik untuk menabung, sehingga dapat menyebabkan terjadinya peredaran uang dalam masyarakat berkurang dan inflasi dapat turun.

\section{SIMPULAN DAN SARAN}

\subsection{Simpulan}

Berdasarkan hasil pembahasan terhadap faktor-faktor yang mempengaruhi tingkat inflasi di Indonesia periode 2000.1-2016.4, dengan menggunakan model koreksi kesalahan model Error Correction Model (ECM) temuan penting yang diperoleh adalah sebagai berikut :

1. Error Correction Term (ECT) adalah signifikan dengan nilai sebesar 3,41 artinya spesifikasi model yang digunakan dalam penelitian ini sudah valid, sehingga mengindikasikan adanya kemungkinan hubungan jangka pendek dan jangka panjang terhadap variabel yang diteliti.

2. Data yang digunakan dalam penelitian ini tidak stasioner dan berintegrasi pada derajat satu atau I (1).

3. Dalam jangka pendek jumlah uang beredar memiliki hubungan yang negatif sedangkan nilai tukar dan suku bunga memiliki hubungan yang positif namun tidak signifikan terhadap laju inflasi. Hal ini terjadi karena kondisi di Indonesia pasca krisis lebih dominan dipengaruhi oleh faktor eksternal yang mempengaruhi inflasi. Disamping itu kebijakan pemerintah dibidang moneter sebagai pengendali jumlah uang beredar di Indonesia kurang berpengaruh terhadap inflasi dalam jangka pendek dan ada kecenderungan lebih banyak dipengaruhi oleh sektor riil. 
4. Dalam jangka panjang, hasil estimasi model koreksi kesalahan Error Correction Model (ECM) menunjukkan bahwa jumlah uang beredar, nilai tukar mempunyai hubungan yang positif dan signifikan. Hasil ini sesuai dengan teori dan hipotesis. Tapi suku bunga berpengaruh positif dan signifikan terhadap inflasi, namun hasil ini tidak sesuai dengan teori dan hipotesis.

\subsection{Saran}

Berdasarkan hasil penelitian, penulis merasa bahwa semakin lengkap variabel yang dianalisis maka hasil yang diperoleh akan semakin baik, oleh karena itu bagi peneliti lanjutan perlu memperhatikan dan mempertimbangkan rentang data dan pengembangan model inflasi.

\section{UCAPAN TERIMA KASIH}

Penulis mengucapkan terima kasih kepada Pimpinan Fakultas Ekonomi dan Bisnis Universitas Tanjungpura (FEB UNTAN yang telah membiayai riset ini dan pihak-pihak terkait yang telah memberikan dukungan terlaksananya kegiatan penelitian.

\section{DAFTAR PUSTAKA}

Amir, A. (2008). Hubungan Inflasi dan Suku Bunga. Retrieved from https://amriamir.wordpress.com/2009/12/02/hubungan-inflasi-dan-suku-bunga/

Boediono. (2006). Teori Pertumbuhan Ekonomi : Seri Sinopsis Pengantar Ilmu Ekonomi No.4. Yogyakarta: BPFE UGM.

Dickey, D., \& Fuller, W. A. (1979). Distribution of the Estimators for Autoregressive Time Series with a unit root. Journal of the American Statistical Assosiation, Vol. 74, pp: 401-419.

Dornbusch, R., \& Fischer, S. (1994). Makro Ekonomi. Alih Bahasa Julius A. Mulyadi. Jakarta: Penerbit Erlangga.

Dumairy. (1987). Kausalitas antara uang beredar dan inflasi di Indonesia. Jurnal Ekonomi Dan Bisnis Indonesia, 2.

Eagle, R. F., \& Granger, C. W. J. (1987). Co-integration and Error Correction Representation, Estimation and Testing. Econometrica, 55, 251-276.

Insukendro. (1993). Ekonomi Uang dan Bank Teori dan Pengalaman di Indonesia (Edisi Pert). Jakarta: BPFE.

Insukindro, \& Aliman. (1999). Pemilihan dan Bentuk Fungsi Model Empirik: Studi Kasus Permintaan Uang Kartal Riil di Indonesia. Jurnal Ekonomi Dan Bisnis Indonesia, 14(4), 49-61.

Jamin, M. . (1990). Monetary Control In A Developing Countries: Indonesian Case. Indonesia.

Mankiw, N. G. (2003). Teori Makroekonomi (Edisi Keli). Jakarta: Erlangga.

Mankiw, N. G. (2006). Principles of Economics, Pengantar Ekonomi Makro. Jakarta: 
Salemba 4.

Mankiw, N. G. (2007). Makro Ekonomi. Erlangga.

Miskhin. (2010). Ekonomi Uang, Perbankan, dan pasar Keuangan. Jakarta: Penerbit Salemba Raya 4.

Nachrowi, D. N., \& Usman, H. (2006). Ekonometrika Untuk Analisis Ekonomi dan Keuangan. Jakarta: Lembaga Penerbit Fakultas Ekonomi Universitas Indonesia.

Nopirin. (2014). Ekonomi Moneter (Edisi 1). Yogyakarta: BPFE.

Pracoyo, T. . K., \& Antyo. (2005). Aspek Dasar Ekonomi Makro di Indonesia. Jakarta: Gramedia Widiasarana Indonesia.

Putra, I. K., \& Meydianawati, L. G. (2014). Analisis Vector Auto Regressive Terhadap Kausalitas Indonesia. E-Journal Ekonomi Pembangunan Universitas UdayaJournal Ekonomi Pembangunan Universitas Udaya, 3, 180-189.

Ramakrishnan, U., \& Vamvakidis, A. (2002). Forcasting Inflation in Indonesia, IMF Workoking Paper 02(111).

Samuelson, P. A., \& Nordhaus, W. D. (2009). Economics (Nineteenth). New York: McGraw-Hill Irwin.

Sriyana, J. (2001). Dampak Eskpansi Fiskal terhadap Inflasi: Studi Empiris Pendekatan ECM. Jurnal Ekonomi Pembangunan, 21.

Thomas, R. L. (1995). Modern Econometric. Addison -Wesley Longman.

Utari, G. A. D., S, R. C., \& Pambudi, S. (2015). Inflasi Di Indonesia: Seri Kebanksentralan (Vol. 23).

Widarjono, A. (2009). Ekonometrika, Teori dan Aplikasi untuk Ekonomi dan Bisnis (Edisi Kedu). Yogyakarta: Ekonisia.

Widiastuti, I. L. (2012). Pengaruh Jumlah Uang Beredar Terhadap Inflasi Di Indonesia Bulan Januari 2001 - Desember 2011: Pendekatan Error Correction Model $(E C M)$. Retrieved from http://e-journal.uajy.ac.id/id/eprint/109 